IRSH 54 (2009), pp. 67-93 doi:10.1017/S0020859009000030

(C) 2009 Internationaal Instituut voor Sociale Geschiedenis

\title{
SURVEY
}

\section{Seamen on Late Eighteenth-Century European Warships*}

\author{
NiKLAS FryKMAN \\ Department of History, University of Pittsburgh \\ E-mail:nfrykman@gmail.com
}

SUMmARY: For hundreds of thousands, the naval wars of the I790s meant shock proletarianization at sea. Unprecedented numbers of men - many without previous experience of the sea, many of them foreign-born - were forced into warships and made to work under the threat of savage violence. Desertion rates reached previously unimaginable levels as men fled ships and navies. The greatest wave of naval mutiny in European history followed in their wake. Hundreds of crews revolted, sometimes paralyzing whole fleets in the midst of the annual fighting season. This article considers the struggles in the French, Dutch, and British navies, concluding that the key development that precipitated the sudden explosion of mutiny was the internationalization of Europe's lower decks.

When the inter-imperial arms race accelerated in the late eighteenth century, European navies entered a three-decade long period of vast expansion. Measured in terms of total displacement, the French navy increased by 107 per cent between 1760 and 1790 ; the Dutch navy by 98 per cent; the Spanish by 85 per cent; the Danish-Norwegian by 34 per cent; and the British navy by 26 per cent. ${ }^{\mathrm{I}}$ Admiralties ordered both more ships and bigger ships, and then crammed more guns into them. They built larger dockyards and more complex bureaucracies, hired more workers, produced and purchased more timber, iron, hemp, and provisions,

\footnotetext{
* A German version of this article will be published in: Marcel van der Linden and Karl Heinz Roth (eds), Über Marx hinaus, Assoziation A (Berlin [etc.], 2009).

I. Jan Glete, Navies and Nations: Warships, Navies and State Building in Europe, I 500-I 860, 2 vols (Stockholm, i993), I, p. 3 I I.
} 
cast more guns, cannonballs, and nails, and constructed docks, warehouses, barracks, and offices. The state financial effort was immense.

Building and arming ships, however, was only part of the challenge. The larger fleets and the near permanent warfare that raged between them also required far more men than were available. By the 1780 s, the French and British war fleets both had manpower needs that were equivalent to all domestically available supply, thus theoretically stripping all non-military shipping of its workers if they were to man all their warships. ${ }^{2}$ The Dutch navy barely managed to scrape together two-thirds of its manpower requirements for the Fourth Anglo-Dutch War in $1780-1784$, and Sweden suffered acute shortages of men during its war with Russia between 1788 and $1790 .{ }^{3}$

European navies met this emergency by expanding their coercive recruitment systems to include groups previously safe from non-voluntary service at sea, and by allowing the proportion of foreign-born seamen on board their ships to expand. But greater numbers of forced workers, as well as more men without any reason to be loyal to the country under whose flag they sailed, drove up desertion rates to previously unimaginable heights. Then came a massive, international wave of mutiny, the like of which had never been seen in Europe's armed forces before, or since. Hundreds of crews revolted, at times disabling whole fleets in the midst of the annual fighting season. By the second half of the I790s, mutineers were executed by the dozen, prompting more violent, more disloyal, more treasonous revolts from below deck. At the end of the century, class war was no longer a metaphor in the wooden world of European warships.

\section{MOBILIZING MANPOWER}

Late eighteenth-century Atlantic Europe is estimated to have been home to around 300,000 to 400,000 skilled seafarers. ${ }^{4}$ The British Isles, with I00,000-I 50,000 men, had the largest concentration, followed by France, Spain, and the United Provinces, each with around 60,000, and DenmarkNorway with approximately $40,000 .^{5}$ These were the men who made up

2. Jean Meyer, "Forces navales et puissances économiques", in Paul Adam (ed.), Seamen in society/Gens de mer en société (Perthes, 1980), pp. 75-90, 78.

3. Otto Emil Lybeck, Svenska Flottans Historia, Andra Bandet, Tredje Perioden: Fran Frihetstidens Slut till Freden $i$ Kiel (Malmö, 1945), p. 420; Jaap R. Briujn, The Dutch Navy of the Seventeenth and Eighteenth Centuries (Columbia, SC, 1993), pp. 195-196.

4. Meyer, "Forces navales", p. 79.

5. Sarah Palmer and David M. Williams, "British Sailors, $1775-1870$ ", in Paul C. van Royen, Jaap R. Bruijn, and Jan Lucassen (eds), "Those Emblems of Hell"? European Sailors and the Maritime Labor Market I570-I870 (Research in Maritime History, No. I3) (St John's, Newfoundland, I997), pp. 93-I 18, I02; N.A.M. Rodger, "La mobilisation navale au XVIIIe siècle", in Martine Acerra, Jean-Pierre Pousson, Michel Vergé-Franceschi, and André Zysberg (eds), État, Marine et Société: Hommage à Jean Meyer (Paris, I995), pp. 365-374, 369; T.J.A. Le Goff, 
the basic pool of naval manpower. Since no major state could afford to maintain a permanently armed fleet, they were mobilized and released as the rhythms of imperial warfare dictated. Whenever peace broke out, hundreds of warships were laid up, and tens of thousands were released onto the maritime labor market. Conversely, when armed conflict was again imminent, European admiralties activated their recruitment systems, and tens of thousands were rapidly sucked back into war work.

The failure to develop a specialized workforce meant that the ability to wage war at sea hinged on the efficiency of the mechanism by which manpower was shifted between the civilian and military sectors. Since demand and supply tended to move in counter-cyclical directions - that is to say, many seafarers were drawn to naval service in peacetime, whereas the merchant fleet attracted them during wartime - this was largely a question of how best to capture and coerce men into service. European navies developed three basic solutions: conscription, impressment, and crimping.

France, Spain, and Denmark-Norway relied predominantly on systems of conscription. Every maritime worker in these countries had to register his name with local state officials, and in return for a number of benefits was ordered to be ready for service whenever called up. Frequency of actual service differed from country to country. In France registered men served every few years for twelve months, while in Denmark-Norway conscripts were only mobilized in times of acute crisis to supplement the small permanent force that was stationed in Copenhagen. ${ }^{6}$

Britain several times attempted the establishment of such a register, but its mariners refused to cooperate, and so the navy continued to rely on the more haphazard, yet astonishingly efficient system of impressment: whenever war threatened, the Admiralty issued warrants, and His Majesty's press gangs came sweeping through port towns and roadsteads,

"The Labor Market for Sailors in France", in Van Royen et al., "Those Emblems of Hell?", pp. 287-327, 300; Meyer, "Forces navales", p. 78; Jaap R. Bruijn and Els S. van Eyck van Heslinga, "Seamen's Employment in the Netherlands (c. I600 to c. I800)", Mariner's Mirror, 70 (I984), pp. 7-20, I0; Gustav Sxtra, "The International Labor Market for Seamen, I600-1900: Norway and Norwegian Participation", in Van Royen et al., "Those Emblems of Hell?", pp. 173-2 10, I 83 ; Hans Chr. Johansen, "Danish Sailors, I 570-1 870", in Van Royen et al., "Those Emblems of Hell?”, pp. 233-252, 242; Henning F. Kiær, "Flådens Mandskap, Nyboder”, in R. Steen Steensen (ed.), Fliden Gennem 450 Ar, 2nd edn (Copenhagen, I970), pp. 234-252, 248.

6. Alain Cabantous, La Vergue et les Fers: Mutins et déserteurs dans la marine de l'ancienne France (XVIIe-XVIIIe s.) (Paris, I984), pp. 82-84; Carla Rahn Phillips, "The Labor Market for Sailors in Spain, I 570-1870", in Van Royen et al., "Those Emblems of Hell?", pp. 329-348, 343; Axel Nørlit, "Tvangsudskrivning og Presning af Mandskap til Flaaden og Defensionen (1 800-07)", Historiske Meddelelser om København, 3 (1942-1943), pp. 353-382; Kiær, "Flådens Mandskab", pp. 246-252; Lars Otto Berg, "The Swedish Navy, I780-1820", in Fred Sandstedt (ed.), Between Imperial Eagles: Sweden's Armed Forces during the Revolutionary and Napoleonic Wars, I780-I820 (Stockholm, 2000), pp. 77-107, 10I-I04. 
forcefully abducting as many men as they could get their hands on, and then distributing them to whatever ship stood in need of manpower. ${ }^{7}$

In the United Provinces, the navy outsourced recruitment. Crimps, commonly known as zielverkopers (sellers-of-souls), preyed on the destitute and desperate, offered them an advance on room and board, and then forced them into the first available warship. The navy then paid the man's wages to the crimp until all his accumulated debts had been cleared. If this system failed to bring in enough manpower, the government sometimes resorted to embargoing all outgoing shipping, a crude but devastatingly effective mechanism for quickly swelling the pool of unemployed and easily recruited workers in the port towns. ${ }^{8}$

The near permanent cycle of warfare that commenced in the 1750 s put considerable pressure on these manning systems. War not only increased the demand for seamen, it also killed them by the tens of thousands. Peacetime seafaring itself already had exceptionally high mortality rates. Alain Cabantous has found that between I 737 and I790, 25 per cent of all Dunkirk seamen died while in their twenties, a proportion broadly equivalent to that of Salem, Massachusetts in the late eighteenth century. ${ }^{9}$

Certain trades, of course, were far more dangerous than others. Workers in local trading and fishing industries only had marginally higher death rates than their shore-bound colleagues, but slave-ship sailors customarily lost 20 to 25 per cent of their fellow crewmen on a single voyage. ${ }^{10}$ But navies were the biggest killers. Between 1774 and 1780 , the British navy lost 0.7 per cent of all its seamen in combat, and 10.5 per cent to disease - nearly 20,000 men. ${ }^{\text {II }}$ The numbers grew worse: during the French Revolutionary and Napoleonic Wars almost 90,000 Royal Navy seamen died, up to 24,000 alone in the Caribbean theatre between 1793 and I $80 \mathrm{I} .{ }^{\mathrm{I2}}$ In France, the administrative and financial collapse of the old navy took an immense human toll: over 8,000 men died when typhus tore

7. J.S. Bromley (ed.), The Manning of the Royal Navy: Selected Public Pamphlets, 1693-I873 (Greenwich, 1976); J.R. Hutchinson, The Press Gang Afloat and Ashore (New York, 1914).

8. J.R. Bruijn, "Seamen in Dutch Ports, c. 1700-1914”, Mariner's Mirror, 65 (1979), pp. 327-337, 33 I-332; C.R. Boxer, The Dutch Seaborne Empire, I600-I800 (Harmondsworth, I973), p. 74; Karel Davids, "Maritime Labor in the Netherlands, I570-1870", in Van Royen et al., "Those Emblems of Hell?", pp. 41-71, 64.

9. Alain Cabantous, "Les gens de mer et la mort: l'exemple de l'amirauté de Dunkerque au XVIIIe siècle”, in Adam, Seamen in Society, pp. I09-I I 8, I09; Daniel Vickers (with Vince Walsh), Young Men and the Sea: Yankee Seafarers in the Age of Sail (New Haven, CT, 2005), p. 108.

Io. Emma Christopher, Slave Ship Sailors and their Captive Cargoes, 1730-1807 (New York [etc.], 2006), pp. I83-184; Marcus Rediker, The Slave Ship: A Human History (London, 2007), p. 244 .

I I. Peter Kemp, The British Sailor: A Social History of the Lower Deck (London, 1970), p. I 39. I 2. Dudley Pope, Life in Nelson's Navy (London, I98I), p. I 3 I; Michael Duffy, Soldiers, Sugar, and Seapower: The British Expeditions to the West Indies and the War against Revolutionary France (Oxford, 1987), p. 334. 


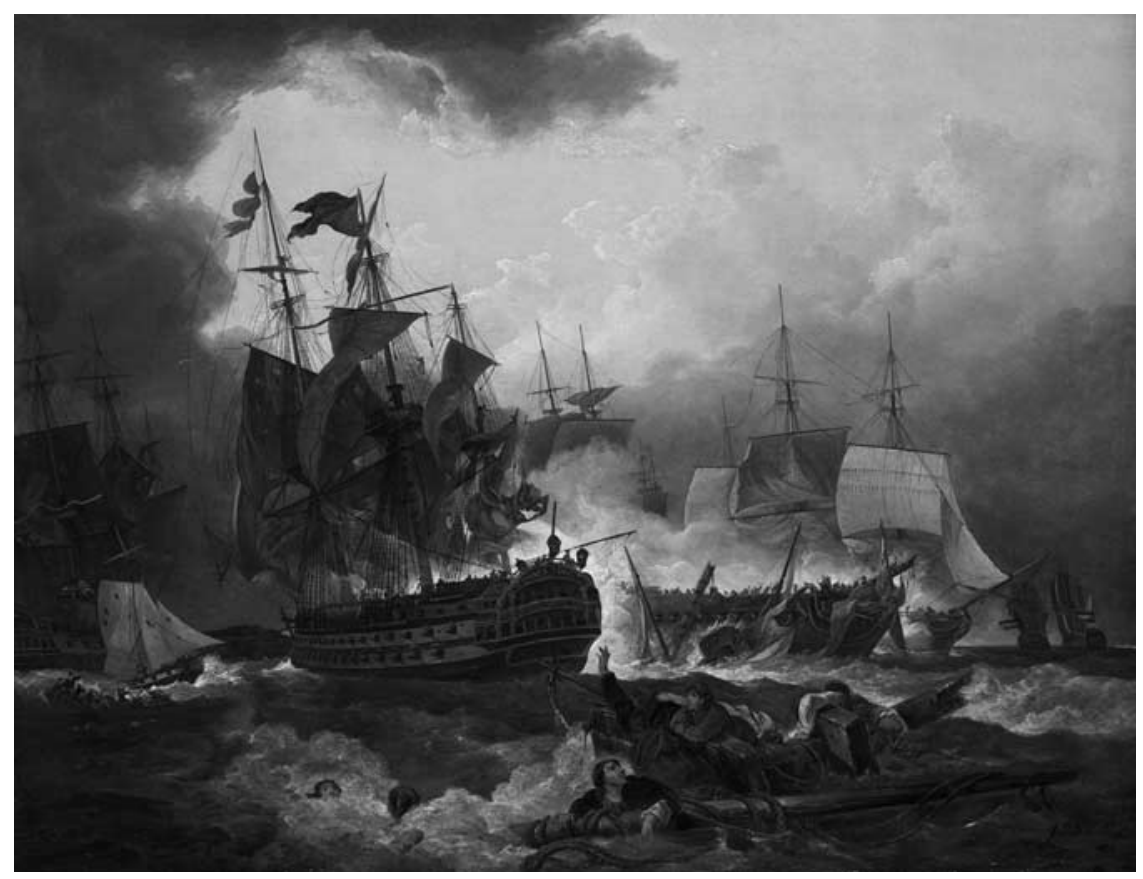

Figure I. Major naval battles were rare events, but they nevertheless killed and mutilated many seamen. The Battle of Kamperduin, fought between the Batavian and British navies on II October 1797 , left 760 men dead and around I,430 men seriously wounded. The British also took hundreds of prisoners.

National Maritime Museum Picture Library. Used with permission.

through Brest in 1793-I794, and this was not the only time or place an epidemic raged out of control. ${ }^{13}$ Several thousand more died in the notoriously lethal British prison hulks. ${ }^{\mathrm{I}}$

Most governments preferred their own country's mariners to man the navy, but by the late eighteenth century that was no longer a viable option. Some provincial ports were ravaged so thoroughly by naval recruiters that they had practically come to a standstill. Seaman William Richardson remembered the huge cost his home town of Shields in northeast England was made to bear: "My brother and I went on shore, but found Shields not that merry place we had hitherto known it; every one looked gloomy and sad on account of nearly all the young men being

I3. Etienne Taillemite, Histoire ignorée de la Marine française (Paris, 2003), p. 284.

I4. T.J.A. Le Goff, "L'impact des prises effectuées par les Anglais sur la capacité en hommes de la marine française au XVIIIe siècle”, in Martine Acerra, José Merino, and Jean Meyer (eds), Les marines de guerre Européennes XVII-XVIIIe siècles (Paris, 1985), pp. 103-122, 103; Carl Roos, Prisonen: Danske og Norske Krigsfanger i England, I807-I8I4 (Copenhagen, I953), pp. I7-I9. 
pressed and taken away; $[\ldots]$ ". ${ }^{\text {Is }}$ This was in 1795 , a mere two years into a war that was to last for twenty more.

One way out of this crisis, adopted especially by the British and Dutch navies, was to recruit foreign-born workers in ever larger numbers. On HMS Hermione, in most respects an ordinary British frigate, only so per cent of the crew came from England, 20 per cent from within the British Empire, another 20 per cent from Ireland, and ro per cent from eleven different countries around the Atlantic rim. ${ }^{16}$ Such a distribution appears to have become common in the late eighteenth-century British navy, but it was nothing compared to the role foreign-born workers played in the Dutch service. ${ }^{17}$ In I799, for example, Captain van Grootenray of the Kortenaar complained that he was unable to communicate with his crew, for almost all of them were fresh recruits from eastern Europe. Worse still, their efforts at Dutch-language acquisition had apparently ceased with the word sold (wages), but that, Van Grootenray reported, they repeated over and over again. ${ }^{18}$ Perhaps the Kortenaar was an extreme case, but indications are that proportions of up to 70 per cent of foreign-born crewmen on Dutch warships were not unusual at the time. ${ }^{19}$

It was nothing new for the Dutch to recruit migratory labor from the North and Baltic Sea regions to work in their deep-sea industries, and the navy utilized these centuries-old networks to the fullest. ${ }^{20}$ This went so far that, even while fighting a war against Britain, there were recruiters doing the rounds in London's sailor-town, busily sending men to Amsterdam by way of the Dutch embassy in Hamburg. ${ }^{2 \mathrm{I}}$ Likewise, the

I5. Spencer Childers (ed.), A Mariner of England: An Account of the Career of William Richardson from Cabin Boy in the Merchant Service to Warrant Officer in the Royal Navy, as Told by Himself (London, 1908), p. I 2 I.

I6. HMS Hermione muster book, April-July 1797, The National Archives: Public Records Office (UK) ADM 36/1201 I; HMS Adventure muster book, January-February 1797, TNA: PRO (UK) ADM 36/1293 I; HMS Success muster book, December 1796-September 1797, TNA: PRO (UK) ADM 36/14745.

I7. N.A.M. Rodger, "Shipboard Life in the Old Navy: The Decline of the Old Order?", in Lewis R. Fischer, Harald Hamre, Poul Holm, and Jaap R. Bruijn (eds), The North Sea: Twelve Essays on the Social History of Maritime Labor (Stavanger, 1992), pp. 29-39, 29-30.

I 8. Captain van Grootenray to Admiral de Winter, I4 July I799, Nationaal Archief, Den Haag, Departement van Marine, I795-I8I3, nummer toegang 2.01.29.0I, inventariesnummer 236.

19. Davids, "Maritime Labor", p. 50.

20. Jan Lucassen, "The International Maritime Labor Market (I6th to I9th Centuries)", in Van Royen et al., "Those Emblems of Hell?", pp. II-23. It is interesting to note that when the commander of the Swedish archipelagean fleet, Mikäl Amkarsvärd, denounced the practices of a local recruiter he used the German translation of the Dutch word for crimp: Seelenverkäufer; quoted in Lybeck, Svenska Flottans Historia, p. 420.

2 I. Extract from a letter from Gravesend, forwarded to Evan Nepean, 26 July 1797, TNA: PRO (UK) ADM I/4173; interrogation of Peter Strouck, NA (NL), Hoge Militaire Rechspraak, I795-I8I3 (I8I8), 2.01.I I, inv. nr. 239. 
Dutch East India Company had a longstanding tradition of recruiting manpower from deep within the rural heartlands of the Holy Roman Empire, and the eighteenth-century navy drew heavily on these sources as well. ${ }^{22}$ Finally, there seems to have been an increase in the number of south, south-east Asian, and African-descended seamen on board Dutch warships. ${ }^{23}$

In the British navy, too, there was a rise in the number of "Black Jacks" and lascars, but the bulk of foreign-born labor power here clearly came from the north Atlantic region. Americans had always been important, and they continued to be pressed with impunity even after independence. ${ }^{24}$ Their numbers were dwarfed, however, by the tens of thousands harvested in Ireland: if, as Rodger plausibly suggests, a proportion of 25 to 30 per cent had become common on most British warships in the late I 790 s, than somewhere around 30,000 Irishmen were serving in the Royal Navy at any one time. ${ }^{25}$

France largely avoided this trend towards increasing the number of foreign-born men in the navy and in 1795 even fixed an upper limit of 20 per cent foreigners on any one ship. ${ }^{26}$ In order to expand the pool of recruits, the French navy chose to make new social groups targets for coerced recruitment instead. The officially defined area where maritime workers may be found - i.e. men subject to conscription - was extended far up the riverine systems, and the number of potential recruits was swelled still further by including economic sectors that only had very indirect connections to the sea. ${ }^{27}$ In Britain, the Quota Acts had a similar effect. Each county, whether maritime or not, was required to send a certain number of men for service in the fleet. Approximately 30,000 came, many of them landsmen who had never set foot on a ship before. $^{28}$

This increased reliance on landsmen was part of a long-term trend in the eighteenth-century maritime industries. By the $1780 \mathrm{~s}$, more than half of all registered seamen in France were first-generation mariners, and in

22. Roelof van Gelder, Het Oost-Indisch Avontuur: Duitsers in Dienst van de VOC (I600-I800) (Nijmegen, I997), pp. 53-70; Davids, "Maritime Labor", p. 5 I.

23. Bruijn, The Dutch Navy, p. 202.

24. George Selement, "Impressment and the American Merchant Marine, I782-I8I2", Mariner's Mirror, 59 (1973), pp. 409-4I8.

25. Rodger, "Shipboard Life", p. 30.

26. "Arrêté du comité de salut public, concernant l'enrôlement des marins étrangers. Du 25 Prairial an III", in Recueil des lois relatives à la marine et aux colonies, I8 vols (Paris, I797-I798), V, pp. 337-340.

27. "Décret sur les classes des gens de mer, 3 I Décembre I790", in ibid., I, pp. 219-227.

28. N.A.M. Rodger, The Command of the Ocean: A Naval History of Britain, I649-I8I5 (New York, 2006), pp. 443-444; Clive Emsley, North Riding Naval Recruits: The Quota Acts and the Quota Men, I795-I797 (Northallerton, I978), pp. I6-21. 
the deep-sea trades their proportion was higher still. ${ }^{29}$ This was a consequence of technical changes, foremost to the arrangement of the rigging on ocean-going vessels, which had devalued the skills and experience of seamen, and instead put an increased premium on their muscle power. The number of able seamen on board transatlantic merchantmen consequently declined by as much as 33 to 50 per cent in the middle years of the century, and in their place came cheap, unskilled workers without much or any experience of the sea. ${ }^{30}$ Work processes were increasingly standardized throughout the industry, and that depreciated the value of the seamen's craft skills still further. ${ }^{3 \mathrm{I}}$ Another set of changes, among them the removal of armaments from merchantmen following the defeat of Atlantic piracy, caused average crew sizes in relation to tonnage to shrink: the organic composition of capital in the deep-sea industries was rising, and that fast. ${ }^{32}$

On warships, the situation was slightly different. While average crew sizes shrunk on merchantmen, navies crammed more and more guns into their ships, and therefore required ever more men to fight its battles. In the late seventeenth-century, a ship of the line had a crew of approximately 500 men; I00 years later crews of 750 were common, and up to 900 far from unheard of. ${ }^{33}$ Since few of these men were needed to sail the ship, and the skills necessary for firing the guns were easily learned, navies had no difficulty absorbing and training large numbers of landsmen. There was, of course, an upper limit. Commander Evertsen found nearly 80 German and Polish landsmen amongst his crew of $\mathrm{I} 20$ when he assumed his position on the Dutch ship Scipio in the summer of 1797 . To put to sea, Evertsen estimated, he needed around 16 more seamen, plus a handful of petty officers. ${ }^{34}$ That would still have left him with nearly 60 per cent landsmen, a figure far higher than was considered desirable in the British navy. There, it seems, the proportion of landsmen and boys was kept below 25 per cent. At the same time, it was only considered necessary to have another 25 per cent experienced and able seamen on board, while the

29. T.J.A. Le Goff, "Les origines sociales des gens de mer français au XVIIIe siècle", in La France d'Ancien Régime: Études réunies en l'bonneur de Pierre Goubert (Toulouse, 1984), pp. $367-380$.

30. Idem, "Offre et productivité de la main d'œuvre dans les armaments français au i 8éme siècle", in Adam, Seamen in Society, pp. 95-108, 104-105; Rodger, "Shipboard Life", p. 30.

31. Marcus Rediker, Between the Devil and the Deep Blue Sea: Merchant Seamen, Pirates, and the Anglo-American Maritime World, I700-1750 (Cambridge, 1987), p. 83.

32. Richard W. Unger, "Regulation and Organization of Seamen in the Netherlands and Germany before the Industrial Revolution", in Adam, Seamen in Society, pp. 66-73, 67-68; Le Goff, "Offre et productivité", pp. I04-105.

33. Meyer, "Forces navales", p. 80.

34. C.G. Evertsen to the Committee for Naval Affairs, 30 July 1797, NA (NL), Departement van Marine, I795-I 81 3, 2.01.29.0I, inv. nr. 236. 
remaining so per cent could safely be made up of low-skilled common ratings, often recent landsmen themselves. ${ }^{35}$

The largest group of new recruits that found themselves on warships in the 1790 s were the sons of the European peasantry. ${ }^{36}$ Massive population growth, coupled with the enclosure of common land, the monetization of rural social relations, and the commercialization of agricultural production, produced a vast landless surplus population, highly mobile, and desperate for work and sustenance. Europe's roads were clogged with men and women seeking a living, and while most of these roads led into the rapidly expanding slums of the cities, there were others that led to the coast. There is a striking correlation, for instance, between the astonishing numbers of landless peasants in Bohemia in the last quarter of the eighteenth century - estimated at 40 to 60 per cent of the total population - and the substantial presence of Bohemians in the Dutch navy at the same time. ${ }^{37}$ This is, of course, merely suggestive, but similar developments can be observed in Ireland, where peasants flooded into the British navy, and rural France where they filled the lower decks of their own country's fleet.

Many new seafarers also came from Europe's urban centers where capitalist deregulation, together with the imposition of the wage-form, smashed the moral economy of the guild system and released artisans, journeymen, laborers, and low-level intellectual workers into market freedom by the hundreds of thousands..$^{38}$ Wartime recession drove them into unemployment and to the brink of starvation. They were easy targets for naval recruiters.

The largest group on board European warships, however, remained the men who were born and bred to the sea. ${ }^{39}$ But these came from two relatively distinct sectors. One was made up of the men of the deep-sea trades who sailed out across the world's oceans to carry back capital and commodities to Europe's major port cities. These were the proletarianized mariners whose dreary lives were essentialized into the well-known stereotype of Jack Tar: deracinated, spendthrift, and impulsive. Their working conditions had been steadily deteriorating since the late Middle

35. J.S. Bromley, "The British Navy and its Seamen: Notes for an Unwritten History", in Adam, Seamen in Society, pp. 36-47, 40; Larry Neal, "The Cost of Impressment during the Seven Years War", Mariner's Mirror, 64 (1978), pp. 45-56, 52.

36. Davids, "Maritime Labor", pp. 62-65; Le Goff, "The Labor Market”, pp. 300-30I.

37. Arnošt Klíma, "Agrarian Class Structure and Economic Development in Pre-Industrial Bohemia", Past and Present, 85 (1979), pp. 49-67, 54; for the number of Bohemians in the Dutch navy, see various muster books in NA (NL), Departement van Marine: Monsterrollen, I795-I 8 I0, 2.01.30.

38. Peter Linebaugh, The London Hanged: Crime and Civil Society in the Eighteenth Century (Cambridge, I992), pp. 402-44I.

39. Le Goff, "Les origines sociales", p. 368. 
Ages, and by the late eighteenth century co-ownership of the cargo had been replaced with straightforward wage payments and limited collective decision-making with the almost boundless powers of the captain..$^{40}$ In the other sector, however, that of local fishing and short-distance merchant shipping, the patriarchal relations of old-regime rural Europe still prevailed. Crews were small, hierarchies flat, cargo ownership shared, and the powers of the captain limited both by custom and the force of communal disapproval in the home port, usually a small town or village where most of the crewmen lived with their families. ${ }^{4 \mathrm{I}}$ Movement between these two sectors was limited, but it appears that an increasing number of men shifted from the shallow- to the deep-sea trades in the later eighteenth century. Long years of naval service, with its socially corrosive and individualizing effects, often made this move one of permanent proletarianization. Many old seafarers struggled to reintegrate into landed society when the wars drew to a close. ${ }^{42}$

\section{LIFE AND DEATH ON A MAN-OF-WAR}

Whatever their life may have been before - experienced mariner, landless peasant, or unemployed artisan - new naval recruits found themselves in a profoundly alien environment. Only very rarely in the eighteenth century did hundreds of men work together in one place, let alone at a single machine as they did on board a warship. Few people had experience with industrial labor discipline, and most barely accepted that the clock might have anything to do with when they ought to be working. ${ }^{43}$ But coming into a warship, new recruits suddenly found themselves in a miniature mass society, physically isolated for long periods of time, with extraordinary levels of internal stratification, complex organizational structures, 24-hour work cycles, constant, close surveillance, and a terroristic justice system. This regime shock-proletarianized tens of thousands.

While a vast number of finely graded social distinctions separated an admiral from the lowliest seaman, shipboard society basically consisted of only four groups. At the top were the commissioned officers, the inhabitants of the quarterdeck, who under the leadership of the ship's commander enjoyed virtually unlimited powers on board. They were of mixed competence and usually drawn from the prosperous middle classes or the aristocracy, although in post-revolutionary France and the Netherlands

40. Unger, "Regulation and Organization of Seamen", pp. 66-68.

41. Ulrich Welke, Der Kapitän: Die Erfindung einer Herrschaftsform (Münster, 1997), pp. I4-24.

42. See, for example, C.S. Forester (ed.), The Adventures of John Wetherell (London, 1954).

43. E.P. Thompson, "Time, Work-Discipline, and Industrial Capitalism", in idem, Customs in

Common: Studies in Traditional Popular Culture (New York, 1993), pp. 352-403. 
where most of the old officer corps was judged politically unreliable they were sometimes drafted from the ranks. ${ }^{44}$ Below the commissioned officer corps came the warrant and petty officers, largely specialist seamen and trained craftsmen, such as caulkers, coopers, carpenters, gunners, and sailmakers. These were career navy men who had slowly built up their positions through years of service. Socially, most of them belonged to the lower deck, but thanks to their experience, skill, and strategic position within shipboard society, they generally were treated with respect by the commissioned officer corps. The same could not be said of the largest group on board, the common seamen. These were at best seen as dumb instruments of the officers' will, at worst as unruly, drunken saboteurs. They were usually divided into two or three ranks, depending on their experience and training, and though some advanced up into the petty officer corps, shipboard social mobility was very limited once a man had become a loup de mer (sea wolf), or, as he was less poetically known in the British navy, an able seaman. The fourth and final group on board were the marines, the onboard police force that protected the quarterdeck. These were generally of proletarian and often foreign origin, unskilled, and widely disrespected by all others on board. Their basic task was to stand guard and look menacing. ${ }^{45}$

Most ships at sea operated a two-watch system: the crew, excepting the shipboard artisan classes, were divided into two identical groups that came on and off duty every four hours. Within both watches, the men were assigned to a part of the ship, reflecting their predominant area of labor. The highest skilled men were sent up into the tops, where they spent long hours in wind and weather bending, loosing, and furling sails. When a man grew too old for the tops, he usually migrated to the forecastle, where duties included handling the front-most set of sails and the anchor. Less experienced seamen and landsmen were ordered either into the waist or the afterguard, where they pulled the heavy ropes and braces that lifted and lowered the major yards and sails of the ship, looked after the livestock, and pumped bilge water. In addition to a watch and a part of the ship, each man also had a number of stations which clearly defined his exact duty for a large number of standard maneuvers, such as mooring and unmooring, weighing, tacking and wearing, lowering and squaring yards, and so forth. In battle, nearly the entire crew was assigned to

44. William S. Cormack, Revolution and Political Conflict in the French Navy, $1789-1794$ (Cambridge, 1995), p. I09; Thea Roodhuyzen, In Woelig Vaarwater: Marineofficieren in de Jaren $1779-1802$ (Amsterdam, I998), p. I23.

45. Seamen sometimes referred to empty bottles as marine officers, indicating just how useful they thought them; Pierce Egan, Grose's Classical Dictionary of the Vulgar Tongue, Revised and Corrected, With the Addition of Numerous Slang Phrases, Collected from Tried Authorities (London, I 823), no pagination. 
the gun-deck, each man again fulfilling a clearly defined role at a specific gun. ${ }^{46}$

From about the mid-century onwards, some navies introduced divisions and squads to facilitate social control on their larger vessels. Under this system, the crew was broken up into small groups of men and put under the immediate supervision of an officer who was held responsible for their good behavior, cleanliness, and general seaman-like development. ${ }^{47}$ The Swedish navy went one step further towards individualized surveillance, issuing each man with a förhallningsbok (behavior book), in which was recorded his experience, training, rating, and disciplinary history. He was expected to carry it with him throughout his naval career and always present it to a new commander upon first mustering. ${ }^{48}$

Yet despite these innovations, the primary mechanism for social control remained the unceasing rounds of never-ending labor on board. The day's work on a typical battleship began at four in the morning, when one of the two watches was ordered to commence holy-stoning the deck, one of the most odious activities on board:

Here the men suffer from being obliged to kneel down on the wetted deck, and a gravelly sort of sand strewed over it. To perform this work, they kneel with their bare knees, rubbing the deck with a stone and the sand, the grit of which is often very injurious. ${ }^{49}$

This continued for three and a half hours until breakfast, after which the other watch was set to holy-stoning for four hours. The crew detested this incessant cleaning of the decks, especially in the winter months - one new recruit was even driven to thoughts of desertion after only a single day of it - but captains nevertheless continued to order it, because quite simply there was little else for the crew to do. ${ }^{50}$

A warship had up to ten times as many men onboard as most merchantmen of similar size, and that meant that in nearly all situations except for battle they were excessively overmanned. This was a problem:

For a sailor to have a moment's leisure is, by many officers, dreaded more than a pestilence. As the real duties of the ship can never occupy the time of half the men employed, the captain has recourse to his invention to find seamen work; for so conscious are the officers that the seamen cannot reflect without being

46. John Harland, Seamanship in the Age of Sail (Annapolis, MD, 1985), pp. 91-94; Brian Lavery, Nelson's Navy: The Ships, Men and Organization, I793-I8IS (Annapolis, MD, 1989), pp. I94-I99.

47. G.J. Marcus, Heart of Oak: A Survey of British Sea Power in the Georgian Era (London, 1975), p. II7.

48. Lybeck, Svenska Flottans Historia, p. 434.

49. William Robinson, Jack Nastyface: Memoirs of an English Seaman (Annapolis, MD, 1973), p. 32 .

50. A British Seaman, Life on Board a Man-of-War (Glasgow, 1829), pp. 28-29. 
sensible that they have been unmeritedly punished, that they have received almost unlimited injury, that they are fearful reflection should make them compare their situation with the rest of their countrymen, with what they themselves once were, and that this reflection should rouse them to vengeance for oppression. ${ }^{5 \mathrm{I}}$

As the majority of the men were impressed, conscripted, or crimped, there was plenty of disgruntlement on the lower deck, and the threat of open disaffection never far away. And so they were kept busy with makework like holy-stoning or endless drills at small arms or the great guns, both of which the men found only marginally less objectionable. ${ }^{52}$

Dinner was served between I 2 noon and I pm, after which one of the watches went back on duty, usually attending to various necessary maintenance work, or more drilling, while the other watch was given leisure time until supper at $4 \mathrm{pm}$. Two half-watches of two hours length followed, making sure that the order of on-duty off-duty was reversed for the following 24-hour period. Finally, between 8 and 9 pm, the hammocks were ordered down and the men of one watch sent to sleep. The watches changed at midnight and again at 4 in the morning, when the first watch of the day began scrubbing the decks again. ${ }^{53}$

Except for a few hours of eating, drinking, and yarning in the late afternoon, seamen's daily lives were thus mostly consumed by disagreeable tasks, or by mind-numbing boredom. When writing his autobiography, Samuel Leech vividly remembered the many lonely hours he had spent on duty as a topman:

Often have I stood two hours, and, sometimes, when my shipmates have forgotten to relieve me, four long, tedious hours, on the royal yard, or the topgallant yard, without a man to converse with. Here, overcome with fatigue and want of sleep, I have fallen into a dreamy, dozy state, from which I was roused by a lee lurch of the ship.

The only thing worse than this boredom, he concluded, was "to be compelled to stand on these crazy elevations, when half dead with seasickness". ${ }^{4}$

Even these discomforts, however, were nothing when compared to "the King of Terrors", those short bursts of intense violence that ruptured the tedium of everyday life and left men traumatized, wounded, and dead. 55 When battle commenced, the ships' gun-decks became an inferno: broadsides were unleashed with eardrum-bursting roars, the smoke and

5. Thomas Hodgskin, An Essay on Naval Discipline (London, I8 I 3), p. 44.

52. Herman Melville, White-Jacket, or The World in a Man-of-War (Oxford, 1990), pp. 66-67.

53. Robinson, Jack Nastyface, pp. 3 I-38; Lavery, Nelson's Navy, pp. 200-203.

54. Samuel Leech, A Voice from the Main Deck: Being a Record of the Thirty Years Adventures of Samuel Leech (London, I999), pp. I4 I-I 42.

55. Ibid., p. 77. 
fire from dozens of great guns saturating the air. When cannonballs struck the hull of a ship, wooden splinters the size of men's thighs tore loose on the inside, severing arms and legs, smashing skulls, and cutting torsos in two as they slashed and hurtled their way across the tightly packed deck. If the battle lasted for several hours, the gun-deck took on the look of a "slaughterhouse": scores of men dead and dying, heaps of unrecognizable human flesh piled high, blood streaming out the scuppers and into the sea. ${ }^{6}$ Down in the hold, the ship's doctor tried to salvage what he could:

The stifled groans, the figures of the surgeon and his mates, their bare arms and faces smeared with blood, the dead and dying all round, some in the last agonies of death, and others screaming under the amputating knife, formed a horrid scene of misery, and made a hideous contrast to the "pomp, pride, and circumstance of glorious war". ${ }^{57}$

Brian Lavery has estimated that serious mental illness was seven times more common on warships than in society at large, and though it may very well be true that drunken seamen more often knocked their heads against wooden beams than did the rest of the population, it seems likely that post-traumatic stress disorder also played a role. ${ }^{58}$

The maintenance of discipline on board warships was never an easy matter. Naval theorists found comfort in thinking of shipboard society with its hundreds of tightly organized workers as "a great machine", operated by a single human agent, the captain. ${ }^{59}$ Seamen, in this vision, were nothing more than "a wheel, a band, or a crank, all moving with wonderful regularity and precision" ${ }^{60}$ Reality, of course, was rather different, and instead of the interlocking wheels of discipline imagined by the theorists, "one universal system of terror" prevailed on most ships. ${ }^{6 \mathrm{I}}$ The men were either unwilling or unable to function like cogs in a machine: they made mistakes, they were slow, they grumbled and complained. Orders, therefore, were frequently accompanied by the "flesh carpenters" - the boatswain and his mates - liberally beating the crew with their rattan canes and ropes' ends to speed up execution. ${ }^{62}$

If seamen actually committed a breach of the ship's many rules, the most common punishment in most navies was flogging with the cat-o'-nine-tails,

56. John Nicol, The Life and Adventures of John Nicol, Mariner (New York, 1997), p. I74; Moreau de Jonnès, Adventures in the Revolution and under the Consulate (London, 1929), p. 66.

57. A British Seaman, Life on Board a Man-of-War, p. I42.

58. Lavery, Nelson's Navy, p. 2 I 5.

59. A Captain in the Royal Navy, Observations and Instructions for the Use of the Commissioned, the Junior, and other Officers of the Royal Navy (London, I804), p. 36.

60. Leech, Voice from the Main Deck, p. 22.

61. Hodgskin, Essay on Naval Discipline, p. ix.

62. A British Seaman, Life on Board a Man-of-War, p. 35 . 
a whip with nine separate two-foot-long cords, each reinforced with several knots. The legal maximum amount of lashes the captain could order without a court martial varied from navy to navy (in the British navy it was twelve, and in the Danish navy twenty-seven), but, with a little creativity, violations could be broken down into many constituent parts, and each punished with that number of lashes. ${ }^{63}$ The frequency of these floggings varied from ship to ship, but if one assumes an average of approximately once every ten to fifteen days, one will not be very wrong.

The articles of war required that serious violations, ranging from derelictions of duty via "buggery" to mutiny, be tried by courts martial, and these had a terrifying arsenal of punishments available to them: solitary confinement, hard labor, pillorying, ducking, branding, pulling out of tongues, severing of hands, keel-hauling, running the gauntlet, flogging round the fleet, hanging, gibbeting, drowning, decapitation, decimation, arquebusing, and breaking on the wheel. ${ }^{64}$ There were several more. It is not clear, however, how frequently the more outrageous of these punishments were actually ordered, but at least in the British navy, hangings and floggings round the fleet with up to 800 lashes were quite common, as was ducking and hard labor in the Dutch navy. ${ }^{65}$

Generally, punishments were carefully orchestrated public events, with mandatory attendance to maximize the spectacular impact of terror. When a man was flogged through the fleet, for instance, he was taken in a boat from ship to ship, and given a certain number of lashes next to each. After a few dozen with the cat-o'-nine-tails, "the lacerated back looks inhuman; it resembles roasted meat burnt nearly black before a scorching fire". ${ }^{66}$ Another eye witness described it as resembling "so much putrified liver" ${ }^{67}$ Still, the lashes kept falling, and often the victim was beaten within an inch of his life. Survivors were left severely traumatized:

Like the scar, that time may heal, but not remove, the flogged man forgets not that he has been degraded; the whip, when it scarred the flesh, went farther: it wounded the spirit; it struck the man; it begat a sense of degradation he must

63. Erik K. Borring, "Livet Ombord: Danske Orlogstogter til Vestindien, I755-1807" (Ph.D., University of Copenhagen, 1998), pp. 39-43; Pope, Life in Nelson's Navy, p. 62.

64. William Falconer, An Universal Dictionary of the Marine, sth edn (London, 1784), no pagination; Lybeck, Svenska Flottans Historia, p. 436; G. Bent Pürschel, "Træk af Flådens Retsvæsen", in Steensen, Fläden Gennem 450 Ar, pp. 308-3 17; "Décret concernant le code pénal maritime (I6, I9 et 2I Août I790)", in Recueil des lois relatives, I, pp. I22-I40; Robinson, Jack Nastyface, pp. I38-I 5 I.

65. For the British navy, see digest of the Admiralty Records of Trials by Court-Martial, From I January 1755 to I January I806, TNA: PRO (UK) ADM I2/24; for the Dutch navy, see various trial records in NA (NL), Hoge Krijgsraad en Zeekrijgsraden, I607-I794, I.0I.45; and NA (NL), Hoge Militaire Rechtspraak, I795-I8 33 (I8 I8), 2.01.I I.

66. Leech, Voice from the Main Deck, p. 28.

67. Robinson, Jack Nastyface, p. I4I. 


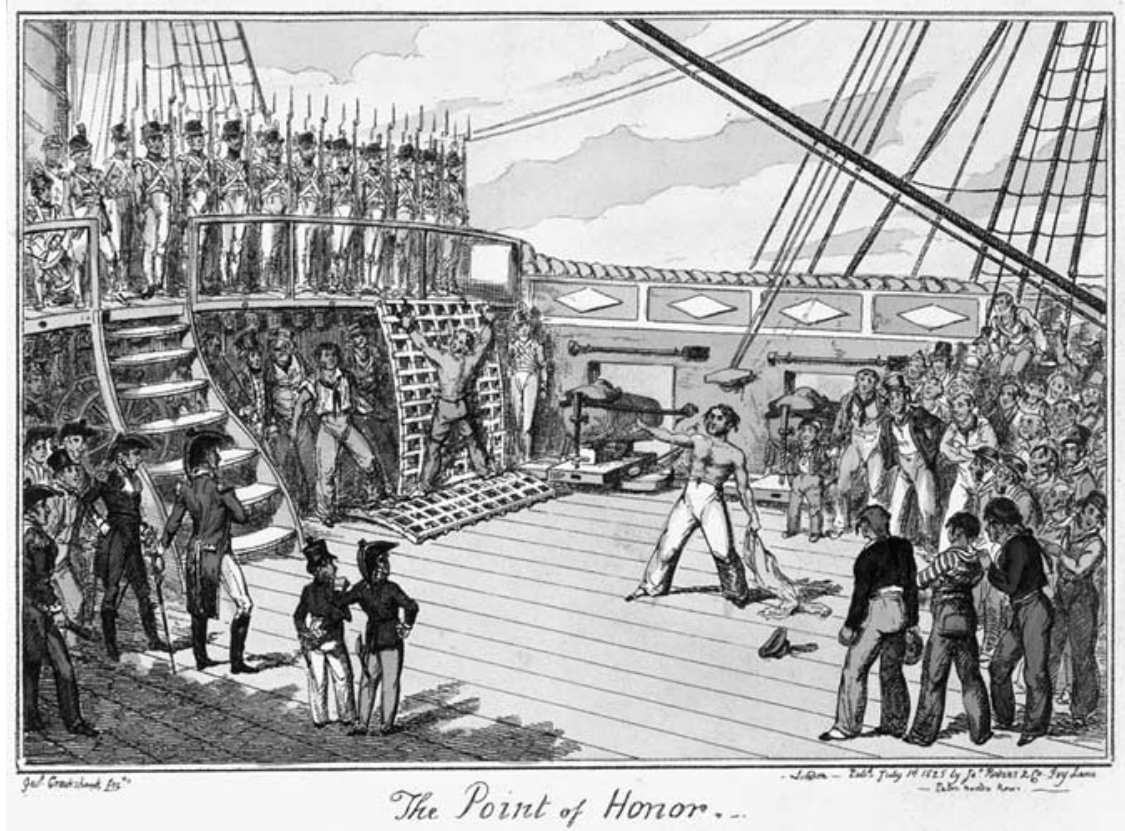

Figure 2. As the major mechanism for enforcing discipline on board of North Atlantic warships, punishment beatings were carefully staged public events with mandatory attendance. They were designed to maximize the spectacular impact of terror.

National Maritime Museum Picture Library. Used with permission.

carry with him to the grave. We had many such on board our frigate; their laugh sounded empty, and sometimes their look became suddenly vacant in the midst of hilarity. IT WAS THE WHIP ENTERING THE SOUL ANEW. ${ }^{68}$

If the sentence called for several hundred lashes, the victim often died halfway through. But the full sentence could be carried out regardless, and the man's comrades were then forced to watch as his dead body continued to be mutilated:

Our captain ordered the doctor to feel his pulse, and found that the man was dead. Our boatswain's mate was then told to give him fifty lashes; "but", says the Captain, "lay them lightly on his back". He might as well have said put them lightly on his bones, for I could not see any flesh on him, from his neck to his waist. After this he was carried to two other ships, and received fifty lashes at each, and then carried to low water mark, and there buried in the mud. ${ }^{69}$

68. Leech, Voice from the Main Deck, p. 60 (emphasis in the original).

69. Joshua Davis, A Narrative of Joshua Davis, an American Citizen, who was Pressed and Served on Board Six Ships of the British Navy (Boston, MA, I8I I), p. 68 (emphasis in the original). 
These clearly were not spectacles meant to instill respect for the service; these were calculated acts of terror designed to cow the lower orders into obedience. They were singularly ineffective.

\section{FRONTLINE RESISTANCE}

Some men were extremely eager to meet with an enemy ship, for combat was considered a great opportunity for "a poor fellow [...] of squaring yards with some of his tyrants" $7^{\circ}$ In the chaos of an engagement, it was easy to swing around with the musket, take aim, and "sweep the quarterdeck of the quality" ${ }^{\text {I }}$ Of course, it is impossible to know how many such "fraggings" actually occurred, but mention thereof is frequent enough to conclude that it was not completely unknown. More common, however, was less lethal violence against individual officers. The ship environment itself offered many possibilities - a tackle dropped from aloft or an iron shot rolled across the deck at night smashed plenty of bones - but most often men out for this type of vengeance appear to have waited for an opportunity to jump their victim on land, preferably as he left a tavern late at night, too befuddled to identify his attackers or make much resistance. ${ }^{72}$

Individual or small-group violence against officers nevertheless was rare. The risks involved were simply too great. If men found a particular situation growing intolerable, they preferred simply to run away instead. It was the mariner's traditional response. Since most of his long-standing social bonds were severed when recruiters forced him into a ship that sailed halfway around the world, leaping overboard and making a run for it when opportunity offered came easy. And judging from the numbers of men who ran, there was no shortage of such opportunities. According to Admiral Nelson's calculations, some 42,000 British seamen took "French leave" between 1793 and 1802 , a figure that is all the more impressive when recalling that the overall strength of the service in 1800 was just under I 20,000. ${ }^{73}$ On some ships, the lower deck apparently had a revolving door: on the frigate HMS Hermione, for example, with a regular complement of approximately 180 men, there were I 29 desertions between 1793 and $1797 .^{74}$

In the French and Dutch navies, the situation was even more extreme, in part because the British blockade kept their fleets bottled up in port for

70. A British Seaman, Life on Board a Man-of-War, p. I28.

71. Court martial against men from HMS Diomede, TNA: PRO (UK) ADM I/5347; Sir Robert Steele, The Marine Officer, or, Sketches of Service (London, I 840), pp. I42-I 43, 205-206. 72. Davis, Narrative of Joshua Davis, 71; John C. Dann (ed.), The Nagle Journal: A Diary of the Life of Jacob Nagle, Sailor, from the Year I775 to I84I (New York, I988), p. 76.

73. Christopher Lloyd, The British Seaman, I200-I860: A Social Survey (Rutherford, 1970), p. 265 .

74. HMS Hermione muster book, April-July i797, TNA: PRO (UK) ADM 36/ı20I I. 
long periods of time, thus giving their seamen plenty of opportunities to desert. The Dutch navy had already been hemorrhaging seamen since the early I 780 s, but with the combined French invasion and revolution of I795, desertion became a mass phenomenon. On many warships, the entire lower deck simply walked away, while on others only skeleton crews remained. On the Staaten Generaal, with a regular complement of 550, only I 22 men were left on board; on the Delft, with 350 men, only Io; on the Castor, with 270 men, only 22; on the Maasnymph, with 75 men, only 29. And so the list continued. ${ }^{75}$ Throughout I796, the navy slowly rebuilt manpower levels, but by the following year desertions once again were rampant. Men kept running in vast numbers until Batavian naval power finally collapsed with the Texel surrender of 1799 .

French seamen were just as footloose, especially during the counterrevolutionary years of the late i $790 \mathrm{~s}$. Thousands deserted to the interior, rejoined their families, or linked up with brigand bands. ${ }^{76}$ Mass desertions in Brest grew to such proportions that the commune periodically felt compelled to close the city gates in order to prevent anyone from leaving town. It did not help. Deserting seamen simply landed outside the walls. ${ }^{77}$ By 1799, the Atlantic fleet was over 8,000 men short, while the Mediterranean fleet at Toulon was missing a full one-third of its regular complement. ${ }^{78}$ Eventually, the back country harbored so many deserters that the government sent the hated colonnes mobiles against them, but even that proved completely ineffectual. Mass desertions continued unabated until the end of the wars. ${ }^{79}$

Seamen in the deep-sea trades had always been enthusiastic deserters, but never on this scale before. In part, perhaps, the spike in desertions, especially to the interior, was due not to seamen, but to the vastly increased number of forcibly recruited landsmen who found life at sea

75. Various court martial cases for desertion, NA (NL), Hoge Krijgrsraad en Zeekrijgsraden, I607-1794, I.01.45, inv. nr. 377; list of ships still in service, February 1795, report of the ships lying at Flushing, 8 March 1795 , and general report on the ships belonging to the central division, I5 March 1795, NA (NL), Departement van Marine, I795-1813, 2.01.29.01, inv. nr. 227.

76. Court martial against André Monfroy et al., Service historique de la Défense, Marine, Vincennes, CC/3/1728, Personnel, Troupes et équipages, Conseils de Guerre, Lorient, I799; Memorandum on Insufficient Punishments of Naval Deserters, SHD Marine, Vincennes, CC/ 3/I47I, Personnel, Troupes et équipages, Mémoirs sur les jurys militaires etc.

77. Captain D'Auvergne, Prince of Bouillon to Secretary Dundas, Jersey, 3 I May I797, TNA: PRO (UK) ADM I/4I72.

78. Vice-Admiral Morard de Galles to the Minister of the Navy and Colonies, Brest, I4 Nivôse Year VII, SHD Marine, Vincennes, BB/3/I 53, Service Général, Correspondance, Brest, I799; Manning levels during Germinal, Year VII, SHD Marine, Vincennes, BB/3/158, Service Général, Correspondance, Toulon, I799.

79. Substance of the last information which has reached me directly from my correspondents in the sea ports, Brest, 20 Floréal Year V, TNA: PRO (UK) ADM I/4I72. 
intolerable and tried to make their way home. But this was often difficult unless they happened to be stationed in their home countries. Having lost their wages by running away, they had few resources to sustain themselves for long, and so in most cases economic pressure or predatory recruitment soon forced them back into service on the first available ship. Frequently that ship sailed under a foreign flag. The men who ran from HMS Hermione after the famous mutiny, for instance, variously ended up on Danish, Spanish, American, Dutch, and British merchantmen, in South American coastal shipping, on French privateers, and in American and even British naval vessels. ${ }^{80}$

Some men consciously chose to switch sides, and some only dreamed of it. John Daley, sergeant of marines on HMS Thames, hoped one day to desert to the French, for he wrongfully believed them "to have no flogging at all" ${ }^{81}$ Others simply ran. William Jetking served as a British soldier in the Low Countries, but as the French army moved north and brought revolution to the United Provinces, he crossed the lines and soon afterwards signed on with the new Batavian navy. When Britain again invaded in I799, Jetking stood ready to defend his adopted republic at sea. ${ }^{82}$ There were many more like him. ${ }^{83}$

More unusual even than the lower deck's high level of cross-border mobility was the astonishing explosion of mutiny that followed in their tracks. In navy after navy, the common seamen refused obedience on a massive scale, and before the decade was out, hundreds of ships' crews had risen on their officers. It began, as so much else in these years, in France. By the time the Committee of Public Safety dispatched Jean-Bon Saint-André to reimpose order on the fleet in 1793 , the lower deck had become almost ungovernable. Revolutionary seamen habitually disregarded their commanders; they organized autonomous councils; they struck for higher wages, for higher invalid compensation, for better treatment of war widows and their children; they rioted through port

80. John Slenison's declaration, TNA: PRO (UK) ADM I/397; John Duncan's declaration, TNA: PRO (UK) ADM ז/73 I; Petition of John Williams, TNA: PRO (UK) ADM I/103 I; Courts martial against men from HMS Hermione, TNA: PRO (UK) ADM I/ 5343 and I/ 5344 ; various letters relating to unrest on HMS Malta, TNA: PRO ADM I/ı०48; "Extract from Captain Thomas Truxtun's Journal, US frigate Constellation, at Hampton Roads, 3 I August 1798, Friday", in Naval Documents Related to the Quasi-War Between the United States and France: Naval Operations from February 1797 to October 1798 (Washington, DC, 1935), p. 365 .

8I. Court martial against men from HMS Thames, TNA: PRO (UK) ADM I/534I.

82. Interrogation of William Jetking, NA (NL), Hoge Militaire Rechtspraak, I795-18 13 ( 18 I 8 ), 2.0I.I I, inv. nr. 238 .

83. List of individuals disembarked at Calais and demanding to serve the republic, Thermidor, Year X - Brumaire, Year XI, Archives Nationales, Paris, F/7/3050, Police Générale, Year IV-I 8 I6. 
towns, wandered on and off their ships at will, threw admirals into prison, sabotaged their ships, refused to put to sea, and soon drove virtually the entire officer corps into exile.

The first major battle erupted in Brest in I790. In August, the National Assembly passed a new code pénal maritime (articles of war) into law, one, it hoped, that would be more compatible with a "free constitution" than the old one had been. ${ }^{84}$ The new principle was to match every conceivable violation with a precise punishment, thus replacing the arbitrary powers of the captain with the predictability of the law. But the crews greeted it only "with contempt", rose up in mutiny, and forced a more thorough revision of the sections dealing with corporeal punishments. $^{85}$

The revolution in St Domingue, meanwhile, radicalized seamen in the West Indian fleet. Mutineers on the Léopard sided with the rebel assembly in Saint-Marc, embarked its members, as well as a number of disobedient soldiers from the Port-au-Prince regiment, and sailed for Brest, where they were greeted as revolutionary heroes. ${ }^{86}$ Suspicion now turned on the role of the officer corps - already unpopular in Brest after the conflict over the new articles - and it became common wisdom that they sought to use the navy as a counter-revolutionary force in the colonies. Seamen were disinclined to be collaborators, and to get that message across they erected gallows in Vice-Admiral Marigny's front yard one night. ${ }^{87}$

In Toulon, three years of conflict between the commune, naval authorities, arsenal workers, and seamen culminated in "the treason" of 1793: a combination of counter-revolutionary plotting and paralyzing internal struggle left port and fleet wide open for the British to seize, and they held on to it until they were driven out by a young Corsican artillery commander, Buonaparte. ${ }^{88}$ The temporary loss of Toulon, the country's second most important naval station, triggered a mass mutiny by radical republicans in the Atlantic fleet, at the time cruising in Quiberon Bay.

84. "Décret concernant le code pénal maritime (I6, I9 et 21 Août 1790)", in Recueil des lois relatives, I, pp. I22-I40.

85. "Rapport sur l'insurrection qui a eu lieu à bord du vaisseau le Léopard", in Recueil des lois relatives, I, p. I66; "Rapport et extrait d'une lettre des commissaries envoyés à Brest, 22 Octobre $1790^{\prime}$, in ibid., pp. 180-184.

86. Various letters and reports in SHD Marine, Vincennes, BB/4/3, Service Général, Campagnes (1790-1913), Iles Sous le Vent, I790; Cormack, Revolution and Political Conflict, pp. $86-87$.

87. “I7 Septembre I790", in L. Esquieu et L. Delourmel (eds), Brest pendant la Révolution (documents inédits): Correspondance de la Municipalité avec les Députés de la Sénéchaussée de Brest aux États Généraux et à L'Assemblée Constituante, I789-I79I (Brest, 1909), pp. 206-208. 88. Jean-Bon Saint-André, Rapport sur la Trahison de Toulon (n.p., n.d.); Cormack, Revolution and Political Conflict, pp. 173-214. 
Afraid traitors were about to hand Brest to the enemy, they formed an autonomous fleet committee and demanded in the name of popular sovereignty that Admiral Morard de Galles take them home. The lower deck had come to consider themselves the guardians of the revolution. ${ }^{89}$

But then came the Terror. In a republic, seamen were reminded, obedience to the state is the first duty of the citizen, and henceforth any unruly behavior, any questioning of authority, any collective petitioning, any refusal of orders, was counter-revolutionary, and it would be dealt with as such..$^{\circ}$ Mutinous seamen were suddenly redefined as standing outside and against the nation, and to make clear what that meant, JeanBon Saint-André ordered a floating guillotine to be constructed, rowed it out into the middle of the Brest roadstead, and there beheaded four mutineers in front of the entire fleet. ${ }^{9 \mathrm{I}}$ A flurry of organizational changes followed, rolling back many of the gains seamen had won since the beginning of the Revolution. Despite occasional outbreaks of major unrest in the coming years - notably at Toulon in I795, Brest and Cadiz in 1796, and on several ships in 1797 - the back of lower-deck insurrectionism was broken..$^{92}$ It was now that mass desertions commenced in earnest.

Just as serious collective unrest was winding down in the French navy, it got underway in the British service. Beginning in 1793 , British seamen launched a series of single-ship mutinies that all, in some way or other, concerned their working conditions. The men of HMS Winchelsea judged their ship unseaworthy, the crew of HMS Windsor Castle wanted less brutal officers, those on HMS Culloden demanded a new ship, the men of HMS Terrible requested better provisions, and the crew of HMS Defiance more alcohol in their grog. ${ }^{93}$ All of these mutinies took the form of the "armed strike": the men went below, turned the guns towards the

89. Revolutionary tribunal of Brest, regarding the insurrection which took place at Quiberon on 13 and 14 September 1793 , SHD Marine, Vincennes, BB/4/3, Service Général, Campagnes (1790-1913), I793.

90. "Décret qui approuve un arrêté pris par les représentans du peuple, pour le rétablissement de la discipline à bord des vaisseaux de la République. Du I6 Nivôse an II", in Recueil des lois relatives, I, pp. $279-288$.

91. Cormack, Revolution and Political Conflict, p. 253.

92. Various letters in SHD Marine, Vincennes, BB/3/85, Service Général, Correspondance, Répresentants en mission, I795; various letters in SHD Marine, Vincennes, BB/3/93, Service Général, Correspondance, Brest, I796; various letters in SHD Marine, Vincennes, BB/3/I I4, Service Général, Correspondance, Brest, I797; various letters and reports in SHD Marine, Vincennes, BB/3/1 19, Service Général, Correspondance, Rochefort, I797.

93. Court martial against men from HMS Winchelsea, TNA: PRO (UK) ADM I/5330; court martial against men from HMS Windsor Castle, TNA: PRO (UK) ADM I/533 I; court martial against men from HMS Culloden, TNA: PRO (UK) ADM I/533I; court martial against men from HMS Terrible, TNA: PRO (UK) ADM I/ 533 I; court martial against men from HMS Defiance, TNA: PRO (UK) ADM I/5334. 
quarterdeck, and then opened negotiations. ${ }^{94}$ But the officer corps, perhaps with an eye towards the aristocrats dangling from lamp-posts across the Channel, was unresponsive. All 5 strikes were broken, I9 men were executed, and I 3 flogged with up to 300 lashes.

But the British lower deck was not about to cave in just yet. In the spring and early summer of 1797 they organized the largest, most sustained working-class offensive of the century: around 35,000 seamen in the home command ran up the red flag of mutiny, asked their officers to leave the ships, and then set about choosing delegates, and forming ship and fleet committees, even electing a president. Then they issued their demands. They wanted guaranteed shore leave and freedom from press gangs; they requested an increase in their wages; they demanded the abolition of officers' disproportionate privileges with regards to prize money; they demanded the right to oust tyrannical commanders; and, when in breach of the articles of war, they wanted to be tried by a jury of their peers, not by a court martial made up only of officers. ${ }^{95}$ Perhaps it was only a coincidence that most of these demands were among the concessions seamen in the French navy had managed to wrest from the state early in the revolution, but perhaps not.

The Admiralty was only prepared to offer an increase in wages - the first in nearly I 50 years - and that proved unacceptable to the more militant wing of the mutineers. After two months, the government therefore sent troops to suppress the mutiny: just over 400 men were arrested, around 60 put on trial, 29 executed, dozens more imprisoned, a number flogged round the fleet, and a handful transported to the penal colony in New South Wales. ${ }^{96}$

Both the form and content of mutinies in the British navy now changed dramatically. Strike-like mutinies nearly disappeared entirely and were instead replaced by shipboard seizures of power. In September I797, the crew of HMS Hermione, having just learnt of the suppression of the fleet mutiny, seized the ship, killed ten of their officers, and then handed the ship over to the enemy. ${ }^{97}$ In the next two years, there were at least twelve serious conspiracies uncovered, all with more or less the same treasonous aims. ${ }^{98}$

94. The phrase "armed strike" is from Jonathan Neale, "Forecastle and Quarterdeck: Protest, Discipline and Mutiny in the Royal Navy, I793-18I4" (unpublished Ph.D. thesis, University of Warwick, 1990).

95. Papers found on board HMS Repulse, I 2 June 1797, TNA: PRO (UK) ADM I/727.

96. Draft list of mutineers, TNA: PRO (UK) ADM $3 /$ I $_{37}$; list of pardoned mutineers sent to Cold Bath Fields Prison in preparation of their being sent to the hulks, TNA: PRO (UK) ADM I/4173; Convicts transported, I787-I809, TNA: PRO (UK) HO I I/I.

97. Statement of service, I789-1839, of Lt David O’Brien Casey (I779-1853), National Maritime Museum (UK), BGR/I 2.

98. Courts martial against men from HMS Tremendous, Diana, Renomee, Caesar, Princess Royal, Haughty, Defiance, Glory, Ramillies, Queen Charlotte, Diomede, and Hope, TNA: PRO (UK) $\mathrm{ADM}$ I/5343, I/5345, I/5346, I/5347, I/5348, I/5350, and I/535I. 
Then, in March I 800 , the men on HMS Danae revolted and sailed the ship to France. ${ }^{99}$ In November of that year, the crew of HMS Albanaise rose and took her to Spain. ${ }^{100}$ In July I 80I, the crew of HMS Gaza mutinied and escaped to Italy. ${ }^{10 \mathrm{I}}$ Finally, in February I 802 , one month before the Treaty of Amiens, the captain of HMS Syren uncovered what turned out to be the last treasonous shipboard conspiracy of the war. ${ }^{102}$

If British mutineers gradually turned towards treason, their counterparts in the Batavian navy were exceptionally disloyal from the start. It began with the Jason in I796. The crew rose on their officers, explained to Captain Donckum that they felt the conditions under which they were expected to work were intolerable, and since they had not signed up to serve under the flag of the republic anyway, they felt no compelling reason to stay in Batavian service. They took the ship to Greenock in Scotland and handed it over to the enemy. Many of the mutineers joined the British army, but the most active among them went into the navy, and no doubt enjoyed the fleet mutinies in the following year. ${ }^{103}$

Only a few weeks after the Jason, mutiny exploded in Vice-Admiral Lucas's squadron at Saldanha Bay in the Cape colony. Within days of entering the bay, the squadron was surrounded by several thousand British land troops and thirteen Royal Navy warships. On half of the Dutch ships, the crews now rose on their officers, broke into the spirit rooms, and nearly beat to death several of their shipmates who were known as Patriots. Lucas called a council of war, and it was its unanimous decision to surrender the squadron to the British. Had it come to an engagement, the council was careful to note in its minutes, the crews of the ships would have been as likely to shoot their own officers as fire on the enemy. ${ }^{104}$ Lower-deck morale probably improved only little when, in October of the following year, the Texel fleet was ordered out to sea to get slaughtered by the British for no apparent reason. As expected, it was one of the bloodiest and most thorough defeats in Dutch naval history, and a

99. Courts martial against men from HMS Danae, TNA: PRO (UK) ADM I/ $/ 5353,1 / 5354$, and I/ 5358 .

I00. Courts martial against men from HMS Albanaise, TNA: PRO (UK) ADM I/5356, I/5360, $\mathrm{I} / 5361$, and $\mathrm{I} / 5362$.

IоI. Courts martial against the men from HMS Gaza, TNA: PRO (UK) ADM I/5359 and I/ 5360 .

102. Courts martial against men from HMS Syren, TNA: PRO (UK) ADM I/5360.

I03. Captain Donckum's report, NA (NL), Inventaries van de Archieven van het Departement van Marine, I795-I 8I 3, 2.0I.29.0I, inv. nr. 45 I; various letters concerning the Jason, TNA: PRO (UK) ADM 98/107 and 99/94.

I04. Vice-Admiral Engelbertus Lucas, Dispatches, 20 August 1796, Captain Adjoint A.J. Knok's report, Conclusions of the Council of War, i6 August 1796, NA (NL), Hoge Militaire Rechtspraak, I795-I8I3 (I818), 2.01.1 I, inv. nr. 22 I. 
substantial number of Saldanha Bay mutineers contributed to it on the British side. $^{\text {Ios }}$

The next year, one of the ships that had been lucky enough to escape the slaughter at Camperdown became the scene of one of the most bloodyminded conspiracies of the decade. Around forty men on the Utrecht nearly all of them hardened veterans, nearly all of them foreign-born, and nearly all of them former deserters - planned to kill every officer on board save for one lieutenant, cut the cable, run up a Danish flag for decoy, and then, if necessary, fight their way passed the batteries guarding the entrance to the Texel roadstead. Their aim was to plunder the ship, and then head for either England or Hamburg. ${ }^{\text {106 }}$

The Utrecht was also involved in the last, catastrophic explosion of unrest in the Batavian navy: the mutiny and surrender of the Texel fleet in the summer of I799. After an overwhelming British force had moved into the Dutch roadstead, all the tensions, all the frustrations, all the mutual hatreds and suspicions - between commissioned and petty officers, between officers and men, between Patriots and Orangists, between Dutch and foreign-born, between seamen and landsmen, ultimately, between men in war and revolution - suddenly, violently broke loose in the Dutch fleet. On some ships, the lower deck - possibly recalling the senseless slaughter at Camperdown two years before - refused to fight, and went Patriot-hunting instead. On others, they did the opposite and instead attacked their officers for cowardice in the face of the enemy. On yet others, they suspected, not without reason, that their commanders had ordered the ships to be blown up rather than surrendered. On nearly all of them, large-scale violence broke out, and several men - most of them known Patriots - were brutally murdered. The fleet was paralyzed, and easy prey for the British. ${ }^{107}$

\section{CONCLUSION}

As fighting season dragged into fighting season, and desertion rates remained high and kept rising, an ever larger number of men grew into hardened veterans with experience of service in several different fleets. Biographies like Carl Ortmann's became common: born in Danzig, he had served in the French navy, been imprisoned by the British, and was hanged for plotting a violent, treasonous mutiny on a Dutch warship.

I05. Captain-Lieutenant Ruijsch to Vice-Admiral de Winter, i 2 July I797, NA (NL), Departement van Marine, I795-I8I3, 2.01.29.0I, inv. nr. 236.

I06. Courts martial against the men from the Utrecht, NA (NL), Hoge Militaire Rechtspraak, I795-I8I3 (I8I8), 2.01.II, inv. nr. 234 .

107. Various interrogation minutes and reports, NA (NL), Hoge Militaire Rechtspraak, I795-I8I3 (I 818), 2.01.II, inv. nrs. 236-42. 
One of his co-conspirators, Louwrens Perinai, was born in Hungary and had served in the Imperial navy in the war against the Ottoman Empire and after that had made his way to the Low Countries. A third conspirator, Daniel Thulander, came from Sweden and had served in the war against Russia between I 788 and I790, after which he had signed on with a merchantman that left him in Amsterdam. ${ }^{108}$ How many such men were drifting around in the Atlantic naval world is difficult to determine, but even if one assumes only a very cautious average of somewhere between Io and 30 per cent foreign-born men in the major fleets, it is clear that their numbers were significant, probably in the tens of thousands.

On many ships, men from a dozen or more countries served together, and even though some of these countries were officially at war with each other, there is surprisingly little evidence of mutual animosity on the lower deck. On the contrary, seamen were renowned for their strong sense of brotherhood, a trait they learnt to prize after spending years working, living, and fighting together in fragile wooden structures on storm-tossed, war-torn seas. Men who were sent up into the yards together during a gale or down on to the gun-deck in a battle had no choice but to learn to trust each other implicitly. Just as importantly, seamen loved to talk about their lives - "a subject", noted Melville, "upon which most high-bred castaways in a manof-war are very diffuse" - and the boredom of naval service gave them plenty of opportunity to do so. ${ }^{109}$ As they sat together night after night, year after year, comparing and collating their experiences, it cannot have failed to escape their notice how similar many of their stories were.

Deracination, followed by coerced servitude and savage discipline, were broadly shared experiences on the lower deck. Regardless of their native country, regardless of the flag they served under, regardless of whether once they had been "outcasts, convicts, foreigners, mechanics, husbandmen, laborers, fishermen, [or] watermen", after a few years of service at sea they became naval war-workers, Atlantic proletarians. ${ }^{\text {IO }}{ }^{\circ}$ Without the emergence of this shared identity, rooted in their collective, borderhopping experience, it is difficult to understand why disgruntled seamen across the Atlantic naval world suddenly stopped running away and turned to mutiny on such a vast scale instead.

Naval authorities were quick to suspect foreign-born men when they contemplated the eruption of increasingly disloyal mutinies and mass

108. Sentence against Carl Ortmann, sentence against Louwrens Perinai, and second interrogation of Daniel Thulander, NA (NL), Hoge Militaire Rechtspraak, I795-18I3 (I8I8), 2.0I.I I, inv. nr. 234 .

I09. Melville, White-Jacket, p. 53.

I Io. A Captain in the Royal Navy, Observations and Instructions for the Use of the Commissioned, the Junior, and other Officers of the Royal Navy, on all the Material Points of Professional Duty (London, I804), p. 36. 


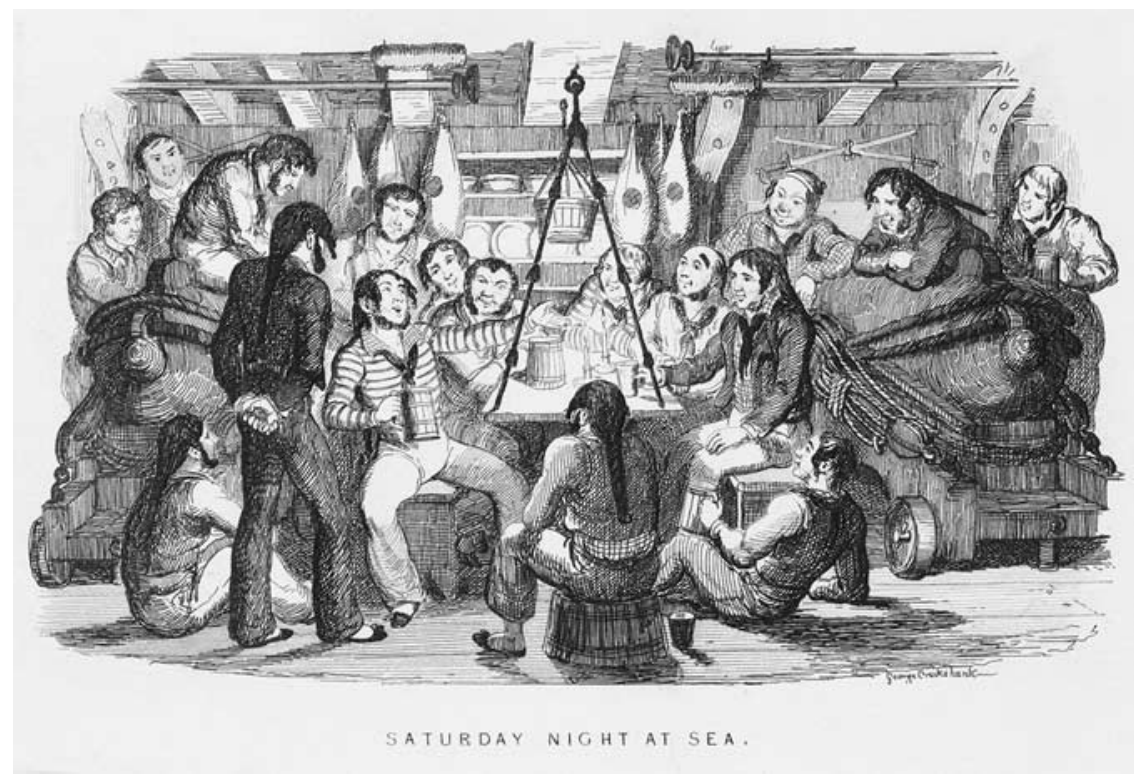

Figure 3. Many warship crews were made up of men from a dozen countries or more. In the cramped conditions below deck, they had plenty of opportunities to share, compare, and collate their many experiences from around the revolutionary Atlantic.

National Maritime Museum Picture Library. Used with permission.

desertions in the later I790s. In France, they worried that their port towns were swamped with "hommes de tous les pays, peu disciplinés, difficilement surveillés" (men of all countries, undisciplined, difficult to monitor), and they constantly suspected them of stirring up trouble. ${ }^{\text {II }}$ Their colleagues in Britain agreed: to them, "Irish and Foreigners" was simply a way of describing potential mutineers. ${ }^{\mathrm{II}}$

It probably appeared comforting to frame the problem in such national terms, but reality was rather different. Foreign-born men were neither more nor less prone to rebel than the native-born, but they did have a particular kind of dangerous influence. Their presence on board built bridges between the lower decks of different navies, and so demystified the enemy. This, in turn, intensified the conflict between forecastle and quarterdeck, for not only were the men brutalized in order to kill and be killed, but they realized they were sent into battle against men very much like themselves. When the men on HMS Pompée conspired to rise on their

I I I. Prefect Maritime Caffarelli to the Minister of the Navy, Brest, i 2 Messidor Year IX, SHD Marine, Vincennes, BB/3/i 8 I, Service Général, Correspondance, Brest, I80 I.

I I2. Vice Admiral Sir Thomas Pasley to the Lords of the Admiralty, Hamoaze, 9 May I799, TNA: PRO (UK) ADM I/8I4. 
officers in June 1797 , hoping thereby to trigger a second fleet mutiny, this time with the aim of forcing the government to make peace, the dangerous potential of this insight became fully apparent. Shortly before the planned insurrection, one of the chief conspirators, William Guthrie, "pointed his hand through the Port towards France and said it is not our Enemies that live there it is our Friends". Such internationalism was intolerable on the frontlines. Three men were sentenced to death, two recommended for mercy, and one condemned to twelve months solitary confinement in the Marshalsea Prison. ${ }^{\mathrm{II}_{3}}$ 